Instructions for Authors: Papers and short notes from contributors anywhere in the world are welcome for consideration for publication in The Lichenologist and may be on any aspect of lichenology.

Manuscripts must be typewritten on foolscap or A4 size paper in double or treble spacing with 1 inch margins all round and submitted in duplicate to the Editor.

Line illustrations must be in black ink on stiff white card, preferably Bristol board.

As a guide to the layout of synonymy, keys, references, etc., recent issues should be consulted. The spellings of locality names in Britain and abroad must follow those of the most recent editions of maps published by the Ordnance Survey and The Times Atlas of the World, respectively. Titles of periodicals should be abbreviated as in the fourth edition of the World List of Scientific Periodicals and its supplements. In lists of references the publisher and place of publication of books should be given; editions other than the first should be indicated.

Copyright/Offprints. Authors submitting a manuscript do so on the understanding that if it is accepted for publication, copyright in the paper for the United States of America shall be assigned to the Society. In consideration for the assignment of copyright, the Society will supply 50 offprints of each paper, but not Short Communications or Book Reviews. Further offprints may be ordered at extra cost at the proof stage. The Society will not put any limitation on the personal freedom of the author to use material contained in the paper in other works which may be published in North America or elsewhere. Reprints must be ordered directly from Academic Press Inc. when the author returns the proofs of his article.

Books dealing with any aspect of lichenology will be reviewed. Publishers wishing to have works reviewed in The Lichenologist should send them to the Editor in the first instance.

This journal is covered by Current Contents and Biological Abstracts.

Notice: While the Editor and Assistant Editors endeavour to check the accuracy of statements in contributions in as far as they are able, it should be emphasized that views expressed in papers in The Lichenologist are those of their authors and do not necessarily represent those of the British Lichen Society, Academic Press Inc. (London) Ltd, the Editor or the Assistant Editors.

Referees: The function of referees is to assist members of the British Lichen Society in the identification of lichens. Specimens submitted should be adequate in size and well documented, including details of country, county or vice-county, borough or parish, precise locality and grid reference, altitude, date, habitat and ecology, notes, name of collector and collecting number. Identification should be attempted before sending material to a referee and details of spores and chemical reactions included where appropriate. Members wishing to send large numbers of specimens to a referee should first of all check that he is willing to name their collections for them. Return postage should always be included.

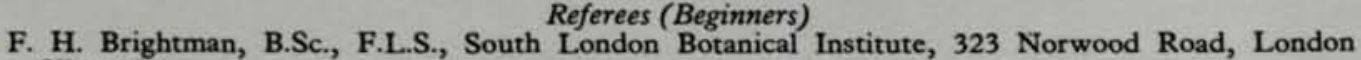
SE24 9AQ.

F. S. Dobson, F.L.S., Richmond Publishing Co. Ltd, Orchard Road, Richmond, Surrey TW9 4PD.

O. L. Gilbert, Ph.D., Address under 'Bulletin Editor'.

D. Jackson Hill, D.Phil., Department of Extra-Mural Studies, The University, Bristol, BS8 1HR.

\title{
Referees (Advanced)
}

B. J. Coppins, B.Sc., Royal Botanic Garden, Inverleith Row, Edinburgh, EH3 5LR. (Bacidia and Micarea spp. only.)

A. Fletcher, Ph.D., Address under 'Conservation Officer'. (Marine and maritime lichens.)

D. L. Hawksworth, D.Sc., F.L.S., Address under 'Editor'. (Lichenicolous fungi.)

P. W. James, B.Sc., F.L.S., Department of Botany, British Museum (Natural History), Cromwell Road, London, SW7 5BD. (All groups.)

J. R. Laundon, F.M.A., Address under 'Secretary'. (Sterile crustose lichens.)

F. Rose, Ph.D., Rotherhurst, 36 St Mary's Road, Liss, nr Petersfield, Hants., GU33 7AH. (Corticolous lichens.)

G. Salisbury, 35 Carrick Road, Curzon Park, Chester, CH4 8AN. (Sand dune lichens, microlichens esp. Thelocarpaceae, Thelotrema s. lat.)

J. W. Sheard, Ph.D., Address under 'Regional Treasurer'. (Buellia, Rhizocarpon, Rinodina.)

L. Tibell, Ph.D., Institute of Systematic Botany, University of Uppsala, P.O. Box 541, S-751 21 Uppsala 1, Sweden. (Caliciales s.lat.) 


\section{THE LICHENOLOGIST}

AHTI, T.-The morphological interpretation of cladoniiform thalli in lichens

ROGERS, R. W.-The corticolous species of Haematomma in Australia

Hawksworth, D. L.-Changes to the British checklist arising from the abolition of later fungal starting points

Hertel, H. \& ZhAO, C.-F.-Lichens from Changbai Shan-some additions to the lichen flora of north-east China

Magnusson, M.-Composition and succession of lichen communities in an inner coastal dune area in southern Sweden

GILBERT, O. L., Fox, B. W. \& PURvis, O. W.-The lichen flora of a high-level limestone-epidiorite outcrop in the Ben Alder range, Scotland

SiddiqI, M. R. \& Hawksworth, D. L.-Nematodes associated with galls on Cladonia glauca, including two new species

GILBERT, O. L. \& LAmbley, P. W.-Field meeting at Ludlow, Shropshire

Coppins, B. J.-Field meeting in Berwickshire

Field AND STUdy Note

McCARTHY, P. M.-Microclimate and a maritime lichen cleft community

BOOK REVIEWS

(C) 1982 British Lichen Society. The appearance of the code at the bottom of the first page of a paper in this journal indicates the copyright owner's consent that copies of the paper may be made for personal or internal use, or for the personal or internal use of specific clients in the U.S.A. This consent is given on the condition, within the U.S.A., that the copier pay the stated per copy fee through the Copyright Clearance Center, Inc., Operations Staff, P.O. Box 765, Schenectady, New York 12301, for copying beyond that permitted by Sections 107 or 108 of the U.S. Copyright Law. This consent does not extend to other kinds of copying, such as copying for general distribution, for advertising or promotional purposes, for creating new collective works, for resale or for copying or distributing copies outside the U.S.A.

Published three times a year for the British Lichen Society by Academic Press Inc. (London) Ltd, 24-28 Oval Road, London NW1 7 DX, England

Free to full members of the British Lichen Society

Printed in Great Britain by Henry Ling Ltd., at the Dorset Press, Dorchester, Dorset 